This article questions the aesthetic criteria that we usually use to analyze and teach about African cinema. 


\section{Audiovisual Production in West Africa: The Integration of New Technical and Aesthetic Forms to the Classical Film Studies Canon Vincent Bouchard}

The digital shift is changing the cinematographic medium in the technical ways of producing and broadcasting audiovisual artifacts, our aesthetic expectations, and how cultural institutions make sense of these aspects. It is a global phenomenon, which takes a specific form in West Africa, where it presents an opportunity and a challenge, requiring cultural institutions to update their understanding of audiovisual production. Based on analysis of recent Francophone West African films, this article questions the aesthetic criteria that we usually use to analyze and teach about African cinema. Beginning with observations of the consequences of the digital shift, it details how aesthetic evolution is an issue for African film studies and audiovisual institutions in West Africa.

I remember when the Festival Panafricain du cinéma et de la télévision de Ouagadougou (FESPACO $)^{1}$ consistently rejected cheap video production, specifically of the Nollywood type (Haynes 2016). Since cinema was then understood from a French point of view, in aesthetic and technical terms, the festival selected movies aimed to mirror a cinéma de qualité close to European standards. As European funding enabled expensive types of production, such movies were seen mainly by film festival audiences. The pertinent opposition was clearly between filmmakers who adhered to the FESPACO model (Austen 2010) and those who wished to reach a larger audience with entertaining, low-cost productions. Of course, this dichotomy was never representative of the actual film production, but was often reaffirmed in official and film critic statements (Ilboudo 1988; Ouédraogo 1995).

At the FESPACO in February 2017, I was impressed by the number of selected movies that resembled popular videos at the narrative and technical levels. I should have expected such changes, knowing that the digital 
shift is changing all aspects of cinematography (Krings and Okome 2013): the concrete technical ways of producing and broadcasting audiovisual artifacts, our aesthetic expectations, and related cultural institutions (Bourdieu 1972). Though this change is happening all around the world, the shift takes a specific form in West Africa. Across the continent, the lack of means of production has historically been a challenge-but not the only one-for filmmakers' creativity. Consequently, this evolution requires all members of cultural institutions to update their definition and understanding of audiovisual production.

This article questions the aesthetic criteria that we usually use to analyze and teach about African cinema. It starts with a series of observations based on the media consequences of the digital shift and the new aesthetic paths being explored throughout West Africa, specifically in recent Francophone production in Benin, Burkina Faso, Ivory Coast, and Mali. It then details how aesthetic evolution is an issue for African film studies in general and the audiovisual institutions of West Africa more specifically.

\section{Observations: Mediatic/Aesthetic Issues}

\section{Recurrent Challenges and the FESPACO Model}

For many African intellectuals, before or immediately after their countries became independent, the pressing question was how to adapt cultural productions to the anticolonial struggle. One of the first questions was how to empower civil society, and the following one was how to denounce colonial values. Last, intellectuals questioned how best to meet the challenges facing the newly founded nations. African cinema developed within this context, and each filmmaker found different answers, considering their cultural background, colonial European influences, and the available means of production. The second challenge was to determine the kind of movies that should be screened in African theaters. In the 1960s, the distribution channels were primarily private and urban, mainly purveying Hollywood films, while a few exceptions were showing a special interest in screening Egyptian or Indian movies.

Au début naturellement, s'agissant essentiellement de gagner de l'argent, les exploitants se sont préoccupés surtout de procurer à une population analphabète, qui découvrirait le cinéma, ce qui était susceptible de l'intéresser. Les films d'action, les westerns américains furent retenus parce que les histories en étaient accessibles à la compréhension du public qui ne parlait pas en général la langue du film. Ces films eurent par la suite la faveur du plus grand nombre, et depuis, ils continuent d'être massivement diffusés en Afrique. 
Of course, at the beginning, the operators were predominantly concerned with making money, and were thus especially concerned with determining what would interest an illiterate population just discovering cinema for the first time. Action films and American westerns were often chosen because the stories were accessible to audiences who generally didn't speak the language of the films. These films were thus favoured by the most number of people, and since, they continue to be widely distributed across Africa. (Vieyra 1975:241, translation by Dana Vanderburgh)

While taking control of their channels of film distribution and public policies, some newly independent governments had ambitious projects. For example, Senegal founded the Actualités sénégalaises, which produced newsreels and educational documentaries. Paulin Vieyra, the officer appointed to organize and manage Senegalese newsreels, was the first African student to graduate from IDHEC, the French film school. With the collaboration of other Senegalese directors educated in Europe, ${ }^{2}$ he trained his fellow filmmakers, created an aesthetic adapted to a large audience, and attempted to export the Senegalese production style to neighboring countries.

African cineastes still struggle with many of the difficulties Vieyra encountered: weak means of production, the necessity of adapting the film aesthetic to local audiences, and difficulty in finding a profitable market for their movies (Boughedir 1987). These challenges are interrelated and strongly influence how African cinema defines itself. For example, even with the creation of the West African economic union (ECOWAS) in 1975, it was easier to import a movie from Europe or America than from another African country. The other pressing issue was linguistic and cultural: how to address audiences that shared few cultural references and in which language to present the screenplay. Private producers were often unable to create a viable film industry with a market large enough to meet the cost-benefit balance, or to find a suitable compromise between their artistic ambitions and national public tastes. Additionally, local states were often too poor to fund ambitious cultural policies-meaning that African cineastes have had to adapt their intentions, projects, and aesthetics to foreign cultural standards. Instead of addressing their movies to popular audiences in their original cultural areas, some have chosen to pander to Western cinephiles or educated African elites.

This tendency is obvious in Francophone Africa, where film directors and technicians, trained mainly in European schools, adhere to mainstream conceptions and practices developed around the predominant model of the author cinema, characterized by the following aesthetic points: the filmmaker initiates and stays central in the creation process, from the first draft until the final cut; when possible, the shooting takes place in a real location, to facilitate a realistic performance by the actors; technicians guarantee the 
recording of perfect images and sounds, regardless of the conditions. This constraining and expensive way to make films explains the development of body institutions (instances, Dubois 1978) particularly for financing and distribution. To acquire a sufficient budget, most of the cineastes shifted toward European sources of funding and festival audiences. That is why we can describe this conception of film under the reductive label of the FESPACO model.

\section{The New Digital Aesthetic}

Since analog video emerged in the 1970s, followed by digital media, African audiovisual creation and distribution experienced important changes. Low-cost production methods offered alternative ways of broadcasting, via short-circuit distribution models. In Francophone Africa, the first change was a significant increase in female directors of documentaries. Soon after, the light video means of production allowed a greater diversity of local TV series. Then, inspired by Nigerian or Ghanaian cinemas, young videomakers experimented with short and long fiction features, achieving popular success. The decentralization allowed by digital media (DVD, internet, and so forth) offered a way to fill local demand at low cost. Since these types of films share similar aesthetic characteristics, we can classify this production under the generic labels of Nollywood films or digital aesthetic.

It would be simplistic to view these models as polar opposites; however, since the audiovisual production is so diverse and its distribution can reach all possible channels, looking at them in relation to each other helps provide a more nuanced understanding. Thus, not all French-speaking filmmakers chose a FESPACO aesthetic, and the difference between classical film and the digital trend can be narrow. For example, Dibril Diop Mambety and Ousmane Sembène preferred lightweight production means, and Jean-Pierre Bekolo and Jean-Marie Téno filmed well-received movies in video. In fact, in West Africa, as elsewhere, two contradictory tendencies emerge: on the one hand, the diversification of artistic practices, in technical and aesthetic terms; on the other hand, a large cross influence among all the kinds of production that stylistically converge.

Since the characteristics of the FESPACO model are already well exposed (Barlet 1996), it is important to explore further the characteristics of the digital aesthetic (Barrot 2009). This aesthetic started to emerge in the 1990s in Nigeria, but only recently has become common in Francophone West Africa. The image and sound quality are low, reflecting the use of accessible types of technologies (mainly cheap video cameras); the flat image affects the contrast and the depth of field, and built-in mics pick up disruptive sounds. Additionally, the use of outdated computer systems forces users to compress the data, further lowering the audiovisual signal strength. These factors are reinforced by poor technical training. 
The recording devices are frequently placed on automatic modes, creating problems with focus and aperture, specifically during dark or night shootings. Similarly, the final audio mix includes background noise at various levels, to the point where dialogue can be difficult to understand. All these technical problems could be a disturbance for an audience with some audiovisual training, but this does not seem to bother the producers or the spectators. However, some online critics highlight these technical defects and the somewhat unpolished acting techniques, as illustrated in an article about Innocent malgré tout (Cod-Jovi 2017), an Ivorian movie in the 2017 FESPACO competition:

En dehors du réalisateur lui-même qui campe bien son rôle, les autres acteurs surjouent énormément faisant plutôt penser à du théâtre. Quelques approximations techniques notamment au niveau des raccords et de la prise de son qui manque d'uniformité, faisant penser aux films de Hollywood qu'il vaut mieux suivre avec la télécommande en main afin de diminuer et augmenter le volume au fur et à mesure que le lecture avance.

Besides the director, who clearly understood his role, the other actors drastically overdramatize their roles, making it more theatrical. Several approximation techniques, particularly at the level of jump cuts and nonuniform sound recording, invoke Hollywood films that would be better to watch with the remote in hand in order to decrease and increase the volume as the film progresses. (http://kaceto.net, translation by Dana Vanderburgh)

As described in this quote, the staging can be artificial. Low-cost budgets require quick production with inexperienced actors and directors. Without proper training, the actors' main influence, outside of similar productions, is local, subregional, or international TV series. Likewise, the screenplays are inspired by similar types of audiovisual production and often contain script errors, simplistic narrative patterns, over-the-top characters, and predictable dramatic plots. Additionally, the dramatic events are generally characterized by overly expressive and extradiegetic music.

Another recurrent element in these examples is scenes or images that, though they have almost no link with the general plot, are inserted into the movie. All the movies mentioned here contain an aerial perspective, shot by a drone. Most of the time, it is a way to situate the action in a specific neighborhood, like Ouaga 2000 in Le dernier tir (Asogba and Bagué 2017) and La forêt du Niolo (Roamba 2017). The local audience can recognize the new urban development and its symbolic proximity to governmental power; other spectators see a wealthy neighborhood, quiet, 

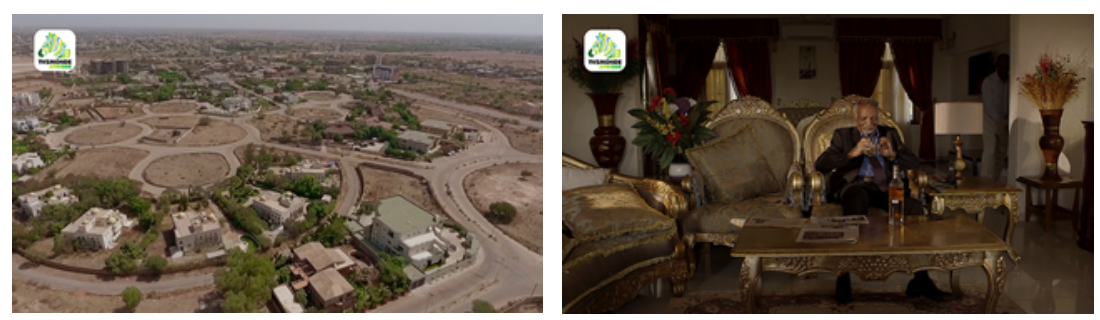

Figure 1. Images from La forêt du Niolo (Roamba 2017).

full of empty spaces and luxurious villas. Much like télénovelas (Fendler 2011), producers frequently include lots of expensive sets or accessories, such as pricey furniture, high-priced cars, or expensive bottles and goods. Every movie thus includes a bathroom scene, which responds to both a Latin American ideal of luxury and the need to reveal the female body in a bath. In the Ivorian movie Innocent malgré tout, the female lead, a senior investigator in the police force, needs to rest and meditate after ordering the torture of an innocent prisoner, and so she takes a bath. We see the same scene in La forêt du Niolo, where the main female character, in mourning after the death of her husband, takes a bath with candles. ${ }^{3}$ This is definitely not a classical aesthetic for a West African movie, and even more surprising considering she is an activist with an NGO that aims to protect water. However, it contrasts the modern way of life chosen by this woman with that of the mature women depicted in the ending scene of the movie, who force open an overarmed, but useless, police roadblock, by defiantly unwrapping their skirts (pagne),$^{4}$ to protest with song in front of the bad guy's house at Ouaga 2000.

As with many Ghanaian productions (Meyer 2005), these movies carry numerous religious references, from daily spiritual practices to Bible quotes. They strongly condemn practices such as drinking alcohol and having nonconjugal sexual relations. For example, in L'interprète (Kone 2017), a woman having an extramarital relationship loses her professional standing and is abandoned by her family. In these movies, the lead characters regularly mention religion as a support: they consult a pastor, or they pray before making important decisions or to find the strength to solve a difficult problem, or for repentance. In Le dernier tir, a police cadet takes a break in the action and prays that he will not become a criminal and will get back on the right moral track. Similarly, the mother of a disabled girl in Abnégation (Olougbegnon 2017) cites religious justification as the reason behind her devotion to help her daughter study; they are filmed reading a biblical passage together. With Innocent malgré tout, we could interpret the entire movie as a present-day reenactment of the Passion of Christ: a poor man, literally searching for meaning among the destitute, is accused, tortured, and hanged for a crime he did not commit. Le dernier tir (not included in the FESPACO selection), Abnégation, L'interprète, and 

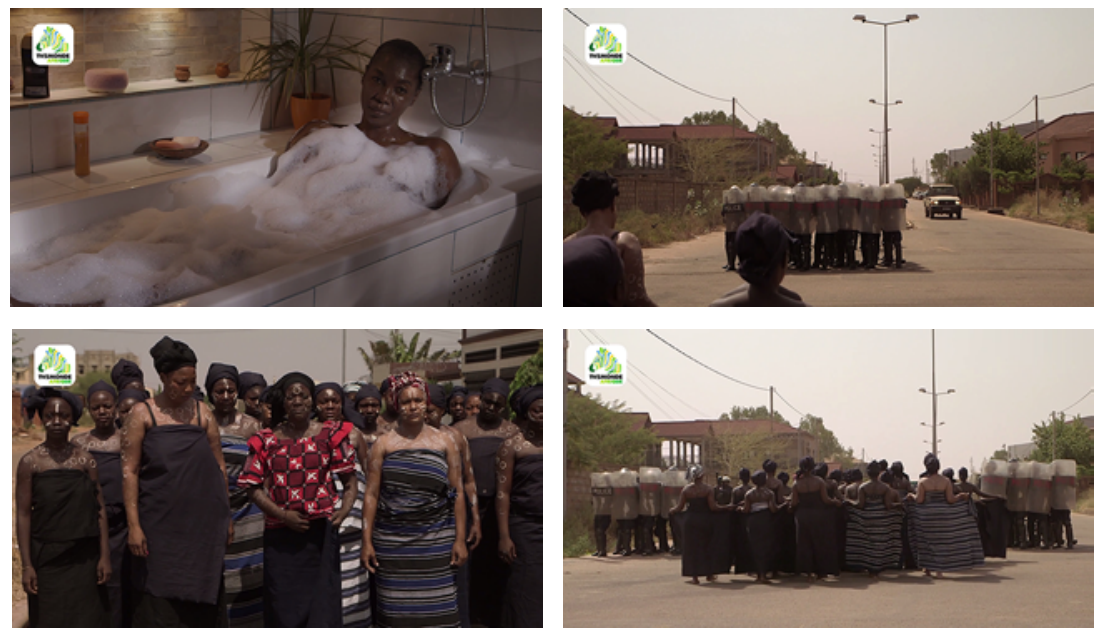

Figure 2. Images from La forêt du Niolo (Roamba 2017).

Innocent malgré tout, aim to please an evangelical agenda: members of such churches were even distributing recruitment flyers before and during the FESPACO's screenings.

\section{New Form of Success}

Innocent malgré tout (no award and no distribution outside of West Africa) was well appreciated by the public during the festival, despite the torture scenes; however, it was unanimously panned by Western film critics, such as Olivier Barlet:

Le summum en la matière était le film ivoirien Innocent malgré tout de Jean de Dieu Konan et Samuel Mathurin Codjovi. Sa présence en compétition est le plus grand coup de couteau que le FESPACO se soit porté. D'une inspiration chrétienne à rapprocher de Mel Gibson et son La Passion du Christ mais strictement dénué de la moindre qualité de cinéma, il se distingue par une bonne vingtaine de minutes de torture, sorte de crucifixion d'un pauvre malheureux accusé à tort d'avoir violé et tué la fille d'un ministre.

The ultimate example in this matter was the Ivoirian film, Innocent malgré tout, by Jean de Dieu Konan and Samuel Mathurin Codjovi. Its presence in the competition was the most unfavorable for the FESPACO. With a Christian inspiration that approaches Mel Gibson's Passion of Christ, but strictly devoid of any cinematic quality, this film differentiates itself with the inclusion of a good twenty minutes of torture, 
a sort of crucifixion of a poor soul wrongly accused of raping and killing a minister's daughter. (Barlet 2017, translation by Dana Vanderburgh)

This contrast with the audience reaction is meaningful: where classic audiences-among them Western film critics who form a formal voice-see a cultural disaster, irrelevant narratives, and problematic technical or aesthetic choices, young popular spectators see an interesting and promising attempt. After one of the FESPACO screenings, ${ }^{5}$ I was puzzled to hear film students praising the technical and narrative qualities of the movie. Though they were dazed by the shocking pictures during the torture scenes, they could explain the rationale behind them in relation to the political message conveyed by the film. The technical weakness was, if I understood them correctly, a way of strengthening the cinematographic discourse to render the plot more realistic.

For Kadhy Touré, the producer and lead actor of L'interprète, ${ }^{6}$ the aesthetic of the film is directly influenced by the production type. For a small company, with little public support, it was difficult to implement the ambitious requirements of a classic technical and aesthetic film:

Je n'ai pas eu de sponsors, je l'ai fait sur fonds propres. Il est compliqué d'avoir des financements pour des films quand on n'a pas un gros nom dans la réalisation, ou un gros nom d'auteur... Mais ce n'était pas évident car la production ça coûte; ... comme je ne pouvais pas laisser mon boulot qui me fait vivre pour simplement tourner, je ne filmais que les weekends, et cela sur plus de deux mois et demi. C'était fatiguant, mais les comédiens ont libéré tous leurs weekends, et ça c'est vraiment la grâce.

I didn't have sponsors. I made the film with my own funds. It is complicated to have financing for films when you do not have a big name in the production team, or a famous actor. However, it was not easy because the production is expensive; ... since I couldn't quit the job that supported me in order to shoot, I filmed only on the weekends for over two and a half months. It was tiring, but the actors freed up all their weekends, and that is really the definition of grace. (Forest 2017, translation by Dana Vanderburgh)

In the same interview, Touré emphasized the necessity of creating a boxoffice hit to gain enough support to start new projects:

Avec le succès en salles je l'ai déjà amorti sur près de $50 \%$ alors qu'il n'est sorti qu'en août 2016, donc on n'a pas encore fini 
les exploitations. Après le Burkina, il part à Yamoussoukro et on va faire d'autres villes de l'intérieur encore. Je ne l'ai pas encore vendu aux chaines de télé. Mais en Afrique pour les longs métrages, quand les salles de cinémas ne marchent pas, tu ne peux pas amortir; si tu as des partenaires, des préachats alors ça ne te dérange pas, mais quand c'est ton propre argent tu es obligée d'amortir sinon tu ne peux pas continuer. Pour moi c'est vraiment le succès en salles qui m’a sauvée.

Due to its theatrical success, I had already recouped close to 50 percent by the time it was released in 2016 , and it had not yet finished its run. After Burkina, it went to Yamoussoukro, and then we went to other towns in the interior. I had not yet sold it to TV channels. However, for feature films in Africa, if the movie theaters aren't operating, you cannot break even; if you have partners and precut deals, you don't have to worry. However, if it is your own money, you must break even, or else you cannot continue. For me, it was truly the theatrical success that saved me. (Forest 2017, translation by Dana Vanderburgh)

Part of cinema production's recipe for success is to offer new stories and kinds of action in a preexisting form that spectators can recognize. Local audiences are already familiar with the digital aesthetic's characteristic types of acting, shooting, and editing. They expect specific narrative and visual elements to appear: bathtub scenes, drone perspectives, expensive sets and accessories, and so forth. All these arguments explain why the standardization of the Nollywood aesthetic is partially determined by the private funding model frequently chosen by West African videomakers in the wake of the digital shift.

\section{Intermediary Model, between Classical and Popular Trends}

Eight of the movies presented in this article were in the official competition (one was in "Films documentaires"), and four of them won five prizes out of the thirty awarded during the closing ceremony: L'interprète was rewarded for the quality of its editing, Ibrahim Koma won the Prix de la meilleure interprétation masculine for his lead role in Wulu (Coulibaly 2017), La forêt du Niolo won for its scenario, and Frontières (Traore 2017) received the prize CEDAO "de l'intégration pour le meilleur film ouest-africain" and prize Félix Houphouët Boigny. Though no critics specifically reported on the editing of L'interprète, Ibrahim Koma's interpretation of a young minibus driver apprentice who becomes a gangster appealed to critics, and the whole movie was generally perceived as well mastered.

The quality of Wulu is attested by selections and awards at other festivals, including Film policier de Beaune, Filmfest Hamburg, FIFF Namur, 
and Toronto. Even if elements of the digital aesthetic appear in it, it is the corpus sample the closest to traditional cinema. Indeed, it is essentially a French production, as it is composed of a team of European technicians (image by Pierre Milon, editing by Julien Leloup), and the technical quality and the actors' performances mirror and reinforce the standards of the FESPACO model. Its director, Daouda Coulibaly, comes from a Malian family, but grew up and was educated in France. His earlier influences were a mix of Malian culture and French urban art, music, and film: French and Hollywood action movies, rap music, and so forth. ${ }^{7}$ Wulu is a hybrid of an action movie (gangster genre), a vernacular Bamana tale, and a reflection on the geopolitical situation in the Sahel.

The writing process proved fruitful for the film, since the young cineaste spent time looking for the most suitable narrative form to tell his story: it was only after several script attempts that he and the producer decided to write a thriller/gangster film:

Au départ, je pensais plutôt écrire une fable. Puis, en discutant avec le producteur, on a pris ensemble conscience du potentiel thriller du film. On a senti qu'on pouvait ajouter les codes de ce genre, en incorporant des scènes d'action par exemple. On a au fur et à mesure senti que c'était une piste à explorer.

At the beginning, I was leaning toward writing a fable. Then, in discussions with the producer, we realized the potential offered by a thriller film. We felt that we could add elements from this genre while incorporating action scenes, for example. We gradually came to the conclusion that it was a path worth exploring. (Dréano 2017, translation by Dana Vanderburgh)

The movie was advertised by the producer as a Malian Scarface. ${ }^{8}$ Similar to Howard Hawks's Scarface (1932) and Brian De Palma's remake (1983), Wulu follows the rise and decline of a criminal, from the early stages in the mafia until his death. Through this individual trajectory, gangster movies describe an outlaw's world based on organized crime, including violent executions and illicit drugs, and its social context of misery and deprivation. The main character engages in illegal activities because of the absence of future prospects. The movie respects the semantic-syntactic characteristics of the genre, but skillfully transposes them into a Senegalo-Malian context.

Wulu is thus an initiation journey, with pertinent references to Bamana culture, including the title: "Wulù veut dire chien en bambara. Le terme correspond aussi à un rite d'initiation dans cette culture. Un chien peut également signifier dans le langage courant un homme sans scrupule." 9 The script, which respectfully depicts a West African way of life, was easily appropriated by the Malian actors and the local audiences. Since the film 
is linguistically and culturally close to the public, the audience can easily appreciate and connect with it. Daouda Coulibaly identifies himself with the heritage of Ousmane Sembène, Souleymane Cissé, and Djibril Diop Mambéty. ${ }^{10}$ As with their works, his film is political. In fact, his primary project was to screen an enlightened reading of the Sahelian crisis, specifically among young citizens, and the film is the product of journalistic investigation: "Le film est très documenté. Beaucoup de livres existent sur le sujet. J'ai rencontré des journalistes, des officiers de police. J'ai lu des rapports sur les activités criminelles dans la région. J'ai intégré cela au fil de mes recherches."11 The Nollywood influence thus appears not to be the filmmaker's primary choice, but a compromise to spread a detailed political message to the broader public. Indeed, Coulibaly successfully exploited digital and genre aesthetics to allow for understanding and consideration. $\mathrm{He}$ achieved this by simultaneously building an intimate connection with the audience while creating distance between them and the depicted reality. ${ }^{12}$

Adama Roamba, the screenwriter and director of La forêt du Niolo (Roamba 2017), made a similar choice for his first full-length feature. After receiving classical audiovisual training that was augmented during his work as an assistant to famous filmmakers such as Dany Kouyaté and Gaston Caboré, he made a series of promising short movies, but he struggled for nearly ten years to finance this particular film. We can therefore conclude that the digital aesthetic is directly linked with the challenges of production. Roamba recounted to $\mathrm{me}^{13}$ the production challenges he encountered. $\mathrm{He}$ was relieved to be able to screen the movie at the FESPACO, and desired success to spread his political message widely. He is concerned by the laissez-faire attitude taken by the Burkinabés' government toward the protection of natural spaces; thus, his film is an attempt to heighten public awareness about this threat. In his opinion, the digital aesthetic of his movie is a compromise between production challenges and the necessity of pleasing the audience to spread a political message. Considering the success of the movie during and after the film festival, one can argue that he achieved his objective. Moreover, the FESPACO prize, sponsored by TV5 Afrique, is a form of validation, since the French TV channel broadcasts and distributes the winning film.

The last film awardee, Frontières, is a reflection on the free movement of goods and people in the ECOWAS (CEDAO) space. A group of women meet in a bus on the Dakar, Bamako, and Cotonou via Ouagadougou route to Lagos. On their journey, they discover the beautiful realities of coastal and Sahelian countries and the perils of such a trip through West Africa: difficulties in crossing borders, different types of trafficking, car breakdowns, coupeurs de route (road bandits), and so forth. Again, this movie does not fit the Nollywood aesthetic perfectly, even if some resemblances are manifest in it. For example, the light means of production gave the crew the ability to follow the actors in real or quasi-real locations. The staging-otherwise excellent-demonstrated aesthetics comparable to African TV series: some 
exaggeration in the acting and a slapstick-esque plot and dialogue. In addition to enabling the filmmaker to produce her project, these aesthetics have been an important factor in the popular success of the movie.

Even if the movies presented in this article share semantic and syntactic elements, they express different styles and ideologies. It would therefore be pertinent to explore more examples and further address the diversity of this aesthetic. However, the chosen examples demonstrate some of challenges and possibilities brought about by digital means of production and distribution. Let us focus now on how they affect our understanding of African cinemas.

\section{Academic Issues}

The consequences of the digital shifts on African cinema are important and permanent, and they challenge us to rethink the way we should study cinema, teach it, and train young filmmakers in the future. Over the past several years, we have adapted the ways we teach and study African cinema and cultures. We have incorporated popular digital productions into our classes and studied the Nollywood miracle (Haynes 2000), Pentecostalist productions in Ghana (Meyer 2005), the "art of video narration in Tanzania" (Krings and Okome 2013), and TV series from Burkina Faso (Fendler 2011). We generally choose a cultural approach, showing how these movies emanate from and reflect a specific culture and interact within a specific sociopolitical context. This raises the question: should we further adapt our methodologies to this new paradigm and change our understanding of what a movie is? How can we analyze these types of production with a more neutral vocabulary?

\section{Stakes for African Film Studies}

The first question brought about by this new trend is the type of films we select: which films should we study and analyze? Changing the corpus to include more technical practices that deviate from the classical Hollywood form (in a studio type of production) - such as products of light means of creation, like videos, blogs, or sketches made and broadcast through a smartphone-and looking at TV series, local productions, and so forth means abandoning practices of film studies that are purely centered on artworks. This problem is not specific to African studies and film studies, but it requires an important change in methodology: how do we and should we study African cinema? This call for change does not focus on a specific aesthetic or a precise conception of film, nor does it advocate bypassing any form of theoretic dogma or artistic canon. At the same time, it advocates moving beyond a cultural approach that views movies only as a carrier of specific representations or as examples of specific lifestyles. 
Following an intermedial approach allows us to focus on how a cultural production interacts with a series of paradigms specific to different cultures through a scheme that meaningfully treats technical media and practices. This methodology includes the description of the context of production and reception as pertinent aspects of an artwork or new aesthetic form. Thus, without focusing on the interpretation of a cinematographic discourse or the characterization of a particular style, this method consists of describing the construction of meaning, in concrete and aesthetic terms. This list of important contextual elements is obviously not exhaustive: the means of production; the structuring effect of the medium; the artistic intentions; the accidents of the creative process; the impact of audiovisual body institutions (Dubois 1978); the economic weight of production and distribution; a specific understanding of the cinematographic medium among creators or audiences; cultural patterns related with long-term influence of audiovisual images; modes of representation, clichés, stereotypes, genre, and other cultural references; and so forth. Of course, if every cultural production is specifically shaped by all these elements, analyzing all of them is nearly impossible and useless. For example, in the first part of this article, some cases were studied from the perspective of the means of production, sometimes in relation to distribution and reception; for others, the cineaste's point of view was pertinent to understand the realization of a preconceived project. The process of creation, as well as the prospective conditions of viewing, could shed light on cases under study. That is why, for example, before criticizing the aesthetic of a certain film, it is important to check the film's reception. This approach, which is not specific to this field, is particularly adapted to these new types of cultural productions, as both artistic practices and means of expression.

\section{Necessity of Teaching Audiovisual Content in West Africa}

If we need to adapt our methodologies to this new trend, it doesn't mean we should give up on the necessity of audiovisual training and education everywhere, and in particular, in West Africa. Broadening audiovisual literacy is important to educate better consumers and citizens, for individuals to be able to better interpret any kind of image, to maintain critical thinking in front of a preformatted message, and to deconstruct and criticize the common modes of representation present in their environment. This training should begin in kindergarten and continue through the university level; however, considering the lack of educational means (for example, in Burkina Faso, some rural schools do not yet have access to electricity), it is important to focus on realistic objectives, meaning precollege (lycée) and college level. This first step would help with the second problem, the formation of the teacher. For example, Ouagadougou University only recently-less than five years ago-created a media school (UFR Arts et Médias), but, as of 2017, students in the schools of education (École nationale des enseignants du primaire) had no access to this training. 
In the short term, specifically in rural areas, the solution is coming from private initiatives like Cinéma Numérique Ambulant (CNA), Cinomade, and Cinétoile (Forest 2016). The CNA network seems to be the most developed so far, and the closest to this aim:

Principe: Le CNA organise régulièrement des tournées "Dix fois Dix [sic] villages." Ces tournées durent six mois au cours desquelles l'équipe de projection parcourt dix villages situés entre 50 et $150 \mathrm{~km}$ d'une ville de base. Chaque village accueille le CNA à dix reprises et accède ainsi à dix programmations différentes. Lieux: En privilégiant les milieux ruraux, le CNA va directement à la rencontre d'un public concerné par un cinéma africain abordant le plus souvent des questions qui lui sont proches. Le CNA véhicule une culture authentique, proche de ses publics. Les soirées du CNA sont avant tout du divertissement, un lieu de vie sociale au sein des villages, de rêve, de rires, d'émotion. Les habitants se retrouvent, sur la place du village, pour vivre ensemble, tous les quinze jours, un moment de fête.

Principle: CNA regularly organizes Ten Times Ten Villages tours. These tours last for six months, during which the production team travels around ten villages that are between 50 and $150 \mathrm{~km}$ from a base village. Each village welcomes the CNA ten different times to screen ten different programs. Locations: In privileging rural areas, CNA goes directly in search of a public that is concerned with an African cinema that touches upon questions that are most relatable to them. The CNA vehicle embodies an authentic culture that is close to its public. The CNA evening screenings are above all, a diversion, a social space in the middle of the village, filled with dreams, laughter, and emotion. The village residents find themselves in the middle of the town every fifteen days to experience a joyous moment together. (CNA website, translation by Dana Vanderburgh)

In doing so, CNA reinforces a film culture by showing its benefits for the community: entertainment, social life, links with vernacular cultures, awareness through fiction, and so forth. By their movie selections, they spread a specific aesthetic, customized to local culture and respectful of high technical standards. Even the FESPACO used to be equipped to screen movies from its collection to popular neighborhoods or villages. This initiative could easily be revived, with some investment, like a fully equipped ciné bus, and the operating cost would likely be moderate, since FESPACO owns the rights of the movies in its collection.

All these public and private initiatives will help the general population better interpret audiovisual images. Cinema is part of general culture: 
watching movies is part of the normal process of knowing and understanding our own culture, and West Africa is no exception. This raises the question of how to put movies and other audiovisual production-publicity clips, news, propaganda, and so forth-into perspective. Of course, this training should be adapted to local cultural contexts, but important issues-like the type of movies to be screened, the aesthetics to be promoted, and the definitions of cinema to be privileged according to specific audiences-remain. Screening movies in different forms of ciné clubs would be beneficial for society in general, not just for creating better educated citizens, but also for the audiovisual industry. In revitalizing the habit of watching movies, these initiatives offer a way to develop and increase spectatorship. Since the audience is the third pillar of the cinematographic institution, it will help stabilize an industry still in its infancy. If viewing and talking about film is a perfect way to start a professional career in the audiovisual world, it could also be a way to increase the technical expectations of the audience, and thus force producers to implement higher standards. How can we explain audience passivity and acceptance of mediocre movies if it is not because of a lack of comparison? What seems acceptable now for the general public could rapidly become unacceptable for more judgmental audiences. That is why a more diverse, wellrounded education should be coupled with better technical training for young professionals. ${ }^{14}$

Burkina Faso is an exception for the quantity of its audiovisual schools, private and public, in Francophone West Africa, but these schools still experience recurrent problems. The top two comments by students concerning their training at the UFR Arts et Médias and the Institut Imagine /Gaston Kaboré) are the lack of funding and production means, and the major discrepancy between training and the professional world: "Hiatus entre les enseignements reçus et les réalités de terrain [au Burkina Faso]."15 The main explanation is that they are taught from a Parisian perspective, by professors educated in French film schools and universities. The most commonly used definition of cinema is based on author cinema theories: cinema art, filmmaker's mode of expression, contrast with genre films, action movies, and so forth. Thus, even if audiovisual equipment is outdated, students are taught old-school cinema techniques (numerous technicians, heavy and bulky equipment, image and sound recorded separately), as opposed to learning light video techniques. Finally, scenario writing and actor techniques clearly align with the French cinema aesthetic. In the absence of drama schools focused on cinema, actors get experience from theater or television series. Filmmakers therefore need to adapt themselves to the actual means of production and the spectators' expectations.

\section{Conclusion}

To refine the actual model further, these observations would need to be based on a broader corpus, for example, through a comparative analysis of 
the FESPACO selection from 1969 up to the present day, and by including selections from other festivals. A further comparative study would show that beyond their cultural, technical, and aesthetic differences, these cinematographic projects touch upon a plethora of concerns, from the complexity of African representations within local and Western cultures, to the impact of media on citizen involvement in public debates. The purpose of this article, however, is to question a methodology, and more specifically, the preconceived criteria we impose onto these movies.

As video changed the conditions of audiovisual production and distribution, the digital shift is a clear acceleration of the decentralization of all body institutions (Dubois 1978). At first, we may observe forms of decentralization; however, it often ends up generating new configurations of the audiovisual industry (Hardt and Negri 2000). For example, in Nigeria, cheap local production, though it still exists, has been overtaken by TV networks that finance, broadcast, and promote specific artists, ideologies, and aesthetics (Haynes 2016). The consequences on African film aesthetics and means of production are important and permanent. The digital shift modifies the reception, on the level of audience expectations, film offerings, and screening conditions. Until now, this technical evolution has allowed African films to renew contact with their audiences. Since the aesthetic and narrative requirements of FESPACO's selection panel have evolved (Barlet 2017), we can observe a convergence of the two models at a time when funding is lacking and it is desirable to reach a more popular audience. It is no longer relevant to put these models into opposition with each other.

Considering all this, we need to adapt the ways we study and teach the production and diffusion of films in Africa. It would be fruitful to expand the canon of audiovisual production under study, and to merge film studies (history, aesthetics, narratology) and cultural studies (modes of representation, cultural patterns) using an intermedial methodology, which in turn would require an interaction with a cultural paradigm specific to a cultural area, the construction of meaning in concrete and aesthetic terms, and meaningful media schemes regarding technical media and practices. At the same time, it is necessary to spread audiovisual literacy in West Africa while adapting film training to match the present-day audiovisual industry. Combining these measures will help grow the audiovisual industry and the cinema institution!

NOTES

1. One of the most important African film festivals, taking place every two years at Ouagadougou, Burkina Faso, since 1969.

2. For more detail on this question, see Bouchard 2017.

3. Regarding the representation of the female body, Burkinabé movies are more conservative than coastal (Ivorian or Ghanaian) movies. 
4. This gesture, revealing their under-pagne (a piece of clothing usually reserved for the intimate sphere), affirms the women's gender power in front of younger policemen: forced to respect social convention, they have to avert their gaze and let them go.

5. March 1, 2017, Institut français.

6. Forest 2017.

7. Forster 2017.

8. Keslassy 2015.

9. "Wulù means dog in Bambara. The term also corresponds to an initiation ritual practiced in this culture. A dog can likewise mean an immoral man in popular speech" (Dréano 2017, translation by Dana Vanderburgh).

10. Forster 2017.

11. "The film was well researched. Many books exist on the subject. I met journalists and police officers. I read reports on criminal activities in the region. I integrated all this into my research" (Dréano 2017, translation by Dana Vanderburgh).

12. "Le genre nous force à regarder les choses avec de la distance" (Dréano 2017).

13. Interview with Adama Roamba, 28 February 2017, Institut français.

14. Exactly what had already happened in Nigeria; for details, see Haynes 2016 and Jedlowski 2011.

15. "A discrepancy between the teaching and the professional realities [in Burkina Faso]" (translation by Dana Vanderburgh) (Justin Ouro, Quelles formations aux métiers du cinéma?, 2017).

\section{FILMS CITED}

Abnégation (Koffi Segla Olougbegnon, Togo, 2017, 60', in the FESPACO competition) Le dernier tir (K. Asogba et A. Bagué, 2017, Burkina Faso, not in the FESPACO selection) Innocent malgré tout (K. Konan, K. Cod-Jovi, 2017, 75', Côte d'Ivoire, in the FESPACO competition) L'interprète (Olivier Meliehe Kone, 2017, 104', Côte d'Ivoire, in the FESPACO competition) La forêt du Niolo (Adama Roamba, 2017, 90', Burkina Faso, in the FESPACO competition) Frontières (Apolline Woye Traore, 2017, 90', Burkina Faso, in the FESPACO competition) Wulu (Daouda Coulibaly, 2017, 95', Mali, in the FESPACO competition) Scarface (Howard Hawks, 1932, 93')

\section{REFERENCES CITED}

Austen, Saul, ed. 2010. Viewing African Cinema in the Twenty-First Century. Athens: Ohio University Press. Barlet, Olivier. 1996. Les cinémas d'Afrique noire, Le regard en question. Paris: L'Harmattan. 2017. Fespaco 2017: Un festival déconsidéré. Africultures: Les mondes en relation, March 8. http:// africultures.com/fespaco-2017-un-festival-deconsidere-14012/.

Barrot, Pierre. 2009. Nollywood: The Video Phenomenon in Nigeria. Bloomington: Indiana University Press. Bouchard, Vincent. 2017. African Documentaries, Critical Interventions: The Non-Fiction Film Production at the Origins of Francophone West-African Cinema. Journal of African Art History and Visual Culture 11(3):214-27. 
Boughedir, Ferid. 1987. Le cinéma africain de Aà Z. Brussels: OCIC.

Bourdieu, Pierre. 1972. Esquisse d'une théorie de la pratique. Geneva: Librairie Droz.

Dréano, Eva. 2017. Daouda Coulibaly, réalisateur du film Wulù. Africa Vivre. https://www.africavivre .com/cote-d-ivoire/a-voir/films/daouda-coulibaly-realisateur-du-film-wulu.html.

Dubois, Jacques. 1978. L'Institution de la littérature: Introduction à une sociologie. Paris: Nathan.

Fendler, Ute. 2011. L'imaginaire télécommandé: La construction identitaire dans les films ouest-africains face à la globalisation médiatique. In Enjeux interculturels des medias: Altérités, transferts et violences, edited by Michèle Garneau, Hans-Jürgen Lüsebrink, and Walter Moser. Ottawa: Presses de l'Université d'Ottawa.

Forest, Claude. 2016. Des villages aux savanes: Le modèle politique et économique du Cinéma Numérique Ambulant en Afrique. Africultures: Les mondes en relation, Aug. 9. http://africultures .com/des-villages-aux-savanes-le-modele-politique-et-economique-du-cinema-numerique -ambulant-en-afrique-13716.

—. 2017. Kadhy Touré: Le cinéma comme business. Africultures: Les mondes en relation, May 30. http://africultures.com/kadhy-toure-cinema-business-14112.

Forster, Siegfried. 2017. Le cinéaste malien Daouda Coulibaly: "Wulu remonte aux racines du terrorisme." RFI, June 14. http://www.rfi.fr/culture/20170614-wulu-cineaste-malien-daouda -coulibaly-racines-terrorisme-air-cocaine.

Hardt, Michaël, and Antonio Negri. 2000. Empire. Cambridge, Mass.: Harvard University Press.

Haynes, Jonathan. 2000. Nigerian Video Films. Ibadan: Kraft.

- 2016. Nollywood: The Creation of Nigerian Film Genres. Chicago: University of Chicago Press.

Ilboudo, Patrick G. 1988. Le FESPACO de 1969-1989, Les cinéastes africains et leurs œuvres. Ouagadougou: Lemante.

Jedlowski, Alessandro. 2011. When the Nigerian Video Film Industry Became "Nollywood": Naming, Branding and the Videos'Transnational Mobility. Estudos Afro-Asiáticos 33: 225-51.

Keslassy, Elsa. 2015. Indie Sales Acquires Malian Crime Thriller Wulu. Variety, Sept. 1. https://variety .com/2015/film/global/indie-sales-acquires-malian-crime-thriller-wulu exclusive-1201582636.

Krings, Matthias, and Onookome Okome, eds. 2013. Global Nollywood: The Transnational Dimensions of an African Video Film Industry. Bloomington: Indiana University Press.

Meyer, Birgit. 2005. Religious Remediations: Pentecostal Views in Ghanaian Video-Movies. Postscripts 1(2):155-81.

Ouédraogo, Hamidou. 1995. Naissance et évolution du FESPACO de 1969 à 1973. Ouagadougou: 1ère Édition.

Vieyra, Paulin S. 1975. Le cinéma africain, des origines à 1973. Paris: Présence africaine.

VINCENT BOUCHARD is associate professor of Francophone studies at Indiana University, Bloomington. He published the book Pour un cinéma léger et synchrone à Montréal (2012), and coedited the issue Le bonimenteur et ses avatars in Cinémas (2010) and the book Dialogues du cinema (2016). He currently works on the reception of colonial and educational screenings in West Africa. 